\title{
STUDY THE ANTIBACTERIAL ACTIVITY OF AQUEOUS EXTRACTION OF ONION (Allium cepaL) AGAINST Staphylococcus aureus ISOLATED FROM OTITIS MEDIA.
}
R. N. Ibrahim
M. S. Alsalmani
Assist. lecturer
T. H. Zedan
Lecturer
Assist. lecturer
Coll.of Biotech.- Un
rsity of AL-Nahrain
011@yahoo.com tam

\section{Coll.of Biotech.-University of AL-Nahrain}

\section{ABSRACT}

This study was aimed to determine the antibacterial activity of onion (Allium cepaL.) aqueous extract against $S$. aureus bacteria isolated from patients with otitis media. Twenty swabs samples were taken from patients with otitis infection; these samples were cultured on different agar media .Results revealed that half of these isolates were related to $S$. aureus and the five of these isolates were subject to sensitivity test against several antibiotic groups. Most of isolates $100 \%$ were resistance to amoxicillin, chloramphenicol, cefoxitin and pencillin, and $60 \%$ of were showed resistance to cefotaxtime and tetracycline, where as $20 \%$ were resistance to Ciprofloxacin. Depending on the results of antibiotic sensitivity, the two isolates(S2,S5) were chosen for determining the minimum inhibitory concentration (MIC) test, $S 2$ isolate showed high-level of resistance at (16 and $128 \mu \mathrm{g} / \mathrm{ml}$ ) to chloraemphenicol, amoxicillin, ampicillin and Cefotaxime respectively, while S5 at concentration (32, 64 and $128 \mu \mathrm{g} / \mathrm{ml}$ ) were resistance to amoxicillin, ampicillin, chloraemphenicol and cefotaxtime. The MIC of onion extract against $S$. aureus was determined at two incubation periods The results were indicated that after $24 \mathrm{hrs}$, MIC of extract at $64 \mu \mathrm{g} / \mathrm{ml}$ was affected in inhibit the growth of S2 isolate, While $32 \mu \mathrm{g} / \mathrm{ml}$ was inhibited the growth of $S 5$ isolate.However, after $72 \mathrm{hrs}$, It was found that the MIC at 32, 64 and $128 \mu \mathrm{g} / \mathrm{ml}$ were more effective in inhibited the growth of S2 and S5 isolates.

Keywords: antibacterial activity, Allium cepa, Staphylococcus aureus, traditional herbal, Otitis media.

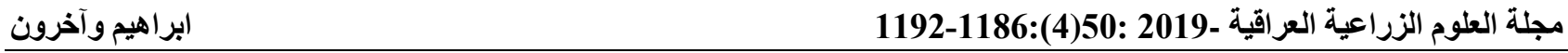

$$
\begin{aligned}
& \text { دراسة التاثير المضاد البكتيري لمستخلص البصل البرلة المائي على بكتريا(Staphylococcus aureus) المزولة من التهاب } \\
& \text { الاذن الوسطى } \\
& \text { تمارا هشام زيدان } \\
& \text { مدرس } \\
& \text { كلية التقتيات الاحيائية/جامعة النهرين } \\
& \text { ريم نعيم ابراهيم } \\
& \text { مدرس مساعد }
\end{aligned}
$$

هدفت هذه الداسة الى تحديد التاثيرالمضاد البكتيري لمستخلص البصل المائي (Allium cepaL) على بكتيريا المكورات العنقودية الذهبية المعزولة

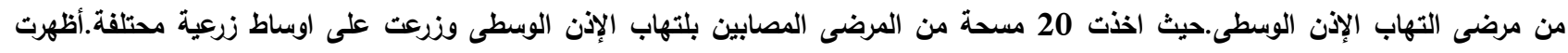

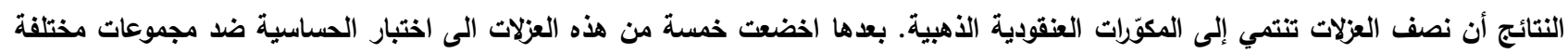

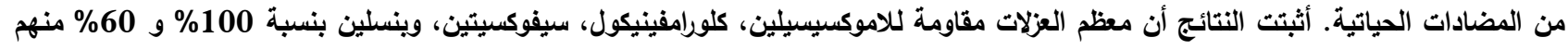

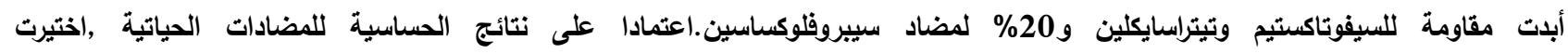

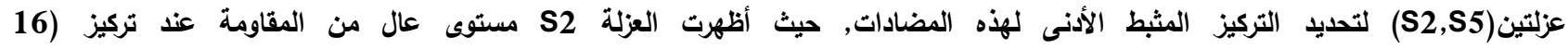

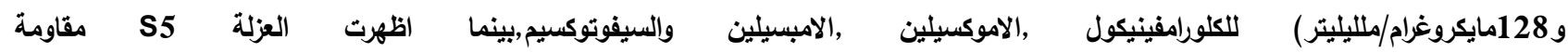

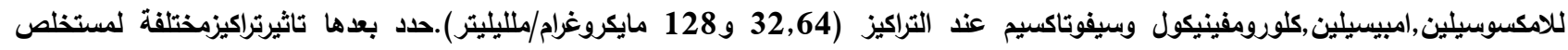

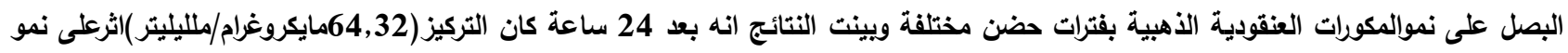
العزلتين, S5,S2 على التوالي بينما بعد مرور 72 ساعة وجد ان التركيز المثبط الادنى(MIC) بتراكيز (128,64, 32 مايكروغرام/ملليليتر) اكثر فعالية في تثبيط النمو S2,S5. الكلمات المفتاحية:مضادات حيوية,بكتريا المكورات العنقودية الذهبية,الاعثاب التقليدية,التهاب الاذن الوسطى,عزلات 


\section{INTRODUCTION}

Medicinal plants, additionally called therapeutic herbs have been found and utilized in conventional drug researches since ancient occasions. Plants synthesize several of chemical compounds for functions including defense against insects, fungi, diseases, and herbivorous mammals. (20) Numerous photochemical with potential or established biological activity have been identified. Further, the phytochemical content and pharmacological actions, if any, of many plants having medicinal potential remain unassessed by research to charecterized efficacy and safety (1).Onion (Allium cepa, L.) considrd as essential dietary intake and have been of critical for medical approach (34). Allium considered as the largest and important representative genus of the Liliaceae family comprises 450 species. Onion (Allium cepa) is a bulbous plant broadly cultivated in almost every nation of the world (18). They are easily propagated, transported and stored and it has diverse biological importance like treatment of cold, heart disease, diabetes, coughs and sore throat (7). Onions has different phytochemical constituents inrichness which clarified is rich in a wide variety of secondary metabolites, such as tannins, terpenoids, alkaloids and flavonoids, which have been found to have antibacterial activities (12).Onion also contained proteins, carbohydrates ,sodium, potassium and phosphorus (26).Onion was expended all through Europe amide and was later thought to guard against evil spirits and the plague, all that due to strong odor (20).In folkloric medicine generally utilized onion to prevent infections and is the oldest cultivated plants utilized both as nourishment and for therapeutic applications (27).The beneficial uses of onion in reduce the risk of certain disease was also investigated for example gastric ulcers by scavenging free radicals and by preventing development of the ulcerforming microorganism, Heliobacter pylori. Also, In vitro onion appered to have antibacterial, antiparasitic and antifungal potential (14).Anciently, Otitis media is inflammation of the middle ear, or middle ear infection. Which occurs in the area between the ear drum (the end of the outer ear) and the inner ear, including a duct known as the
Eustachian tube (17). In children and adults, these disease considered as a major problem since ancient time which require specific treatment because it is leading to hearing loss in children (9)(15).

\section{MATERIALS AND METHOD \\ Collection of plant materials}

The plants were collected from the confined markets during September (2017), and identified previously by National Herbarium of Iraq.

\section{Preparation the aqueous onion extract}

The onion bulb was cleaned from dust by using sterile distilled water, then removing the outer cover of the bulb. (21).Peeled out manually and soaked with distill water, $200 \mathrm{~g}$ of the onion bulb were cut into small pieces and grinded, then soak with $100 \mathrm{ml}$ of distilled water for $24 \mathrm{hrs}$ (13). The extract was filtered with Whitman no. 1 filter paper and evaporate at $45^{\circ} \mathrm{C}$ for drying. Then stored in sterile condition at $4^{\circ} \mathrm{C}$ until use to prepare the required concentrations (31).

\section{Preparation of different concentrations of onion}

Five concentrations $(128,64,32,16$ and 8 $\mu \mathrm{g} / \mathrm{ml}$ ) of onion extract were prepared according to method of Mohamed Eltaweel. 2013. (28) by resuspending the onion extract in sterile distilled water.

\section{Bacterial isolation}

Twenty ear samples were collected from patients suffering from middle ear infection (otitis) from Al-Yarmook Teaching Hospital in Baghdad from the periods (1/9/20171/11/2017) using sterile cotton swab these were processed for direct examination and cultivation on blood agar media, macConkey agar and brain heart agar media (Bangalore, India) and were identified initially as Staphylococcus species according to their morphological, physiological and biochemical properties as indicated by Baird-Parker AC. 1963 (24) by using Gram stain , colony shape, oxidase , catalase, growth on manitol salt agar, growth at 15 and $45 \mathrm{C}^{\mathrm{o}}$.

\section{Inoculums preparation}

Nutrient broth was used to cultivate the isolate of the tested bacteria for 18 hour.Then It was standardized according to National Committee for Clinical Laboratory Standards (30) (NCCLS, 2002) by gradually adding normal 
saline to compare their turbidity to McFarland standard of 0.5 which is approximately $1.0 \times$ $10^{6} \mathrm{cfu} / \mathrm{ml}$.

\section{Antibiotic susceptibility}

Disc diffusion method was used in this study against 5 isolates of $S$. aureus depending on the Kirby-Bauer diffusion method (23) Up to 7 different groups of discs of the available antimicrobial agents (chloraemphenicol, amoxicillin, ampicillin, cefotaxtime, iprofloxacin, cefoxitin and tetracycline) were used in this study.

\section{Minimum inhibitory concentration}

In this experiment Broth micro dilution method was performed, in two fold dilutions of antibiotics were done in broth media and broth was inoculated with $10^{6} \mathrm{CFU} / \mathrm{ml}$ of the tested organisms (2). After incubation for (1824) hrs, the MIC was determined as concentration in which no visible growth was observed (4).

\section{Antibacterial potential of the plant}

The method of Karam, I. F.A. 2016 (22) was followed in assessment of antibacterial activity of plant crude extract in accordance agar-well diffusion method. After growing bacteria in a nutrient broth for 18 hour and standardized to $0.5 \mathrm{McFarland}$ standards $\left(10^{6} \mathrm{cfu} / \mathrm{ml}\right) .200 \mu \mathrm{l}$ of the standardized cell suspensions were spread on a Mueller-Hinton agar, following that wells bored into agar with $6 \mathrm{~mm}$. Then 50 $\mu l$ of the aqueous crude extract suspensions were added at different concentrations $(8,16$, 32,64 and $128 \mu \mathrm{g} / \mathrm{ml}$ ) and allowed to stand at room temperature for about $2 \mathrm{~h}$ and then incubated at $37^{\circ} \mathrm{C}$. The same procedure was followed for control set by using the solvent and distilled water. Then the zones of inhibition after $(24 \mathrm{~h})$ was measured.

\section{RESULTS AND DISCUSSION}

The results in Table 1 indicated that resistance to antibiotics was widely distributed among isolates, however, they varies according to types of the isolates and kinds of antibiotics, All isolates ( 1 1, S2, S3, S4 and S5) were resistance for (amoxicillin, chloramphenicol, cefoxitin, penicillin) respectively, Where as three of isolates showed resistance to cefotaxime (S2, S3 and S5), While(S1and S4) were sensitive to cefotaxime and three of them resistance to tetracyclin (S1, S2, S3) ,Also $(\mathrm{S} 4, \mathrm{~S} 5)$ were sensitive to tetracyclin, while all isolates showed sensitivity to ciprofloxacin except (S5) which was resistance to this antibiotic.

Table 1. Antibiogram of $S$. aureus isolates isolated from otitis patients

\begin{tabular}{|c|c|c|c|c|c|c|c|}
\hline Isolate No. & $\begin{array}{c}\text { CTX } \\
\text { (10) } \mu \mathrm{g}\end{array}$ & $\begin{array}{c}\text { AMX } \\
\text { (10) } \mu \mathrm{g}\end{array}$ & $\begin{array}{c}C \\
\text { (30) } \mu \mathrm{g}\end{array}$ & $\begin{array}{c}\text { CIP } \\
\text { (5) } \mu \mathrm{g}\end{array}$ & $\begin{array}{c}\text { FOX } \\
\text { (30) } \mu \mathrm{g}\end{array}$ & TE (30) $\mu \mathrm{g}$ & $\begin{array}{c}P \\
\text { (10) } \mu \mathrm{g}\end{array}$ \\
\hline S1 & $\mathbf{S}(27 \mathrm{~mm})$ & $\mathbf{R}$ & $\mathbf{R}$ & $\mathbf{S ( 2 3 m m )}$ & $\mathbf{R}$ & $\mathbf{R}$ & $\mathbf{R}$ \\
\hline S2 & $\mathbf{R}$ & $\mathbf{R}$ & $\mathbf{R}$ & $\mathbf{S}(\mathbf{3 0} \mathrm{mm})$ & $\mathbf{R}$ & $\mathbf{R}$ & $\mathbf{R}$ \\
\hline S3 & $\mathbf{R}$ & $\mathbf{R}$ & $\mathbf{R}$ & $\mathbf{S}(\mathbf{3 0} \mathrm{mm})$ & $\mathbf{R}$ & $\mathbf{R}$ & $\mathbf{R}$ \\
\hline S4 & $\mathrm{S}(13 \mathrm{~mm})$ & $\mathbf{R}$ & $\mathbf{R}$ & $\mathbf{S}(\mathbf{3 0} \mathrm{mm})$ & $\mathbf{R}$ & $S(15 \mathrm{~mm})$ & $\mathbf{R}$ \\
\hline S5 & $\mathbf{R}$ & $\mathbf{R}$ & $\mathbf{R}$ & $\mathbf{R}$ & $\mathbf{R}$ & $\mathrm{S}(\mathbf{1 2 \mathrm { mm } )}$ & $\mathbf{R}$ \\
\hline
\end{tabular}

S: Sensitive R :Resistant CTX: Cefotaxime AMX: Amoxicillin P: Penicillin

C: Chloramphinicol CIP: Ciprofloxacin FOX: cefoxitin TE: tetracycline

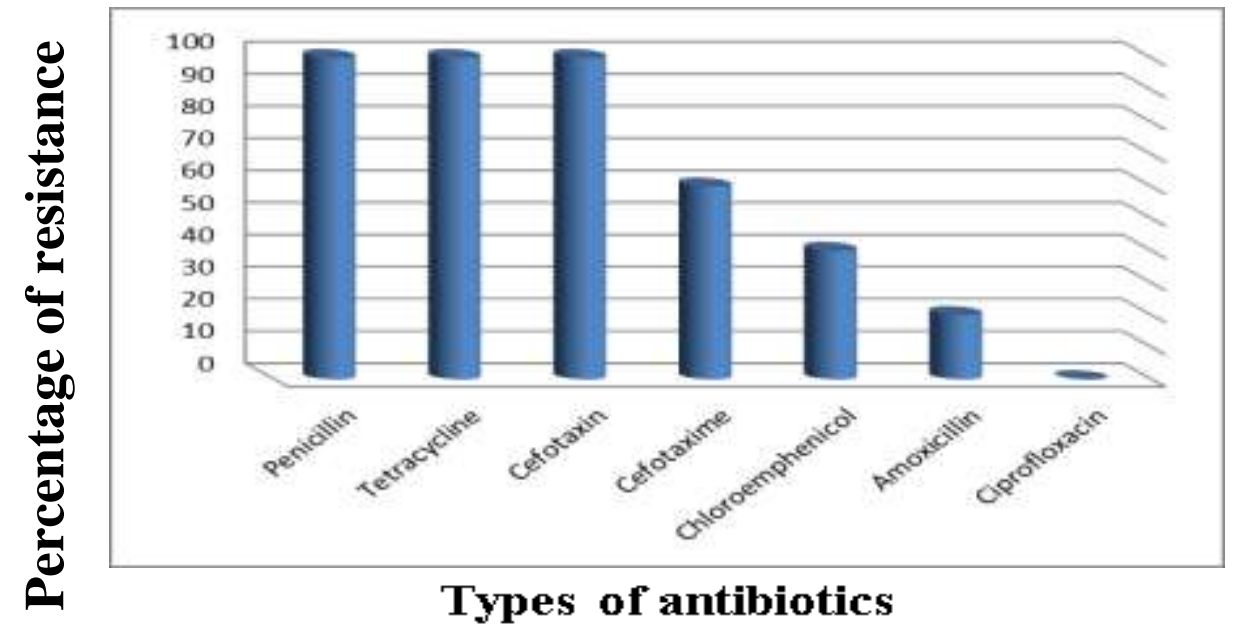

Fig 1. Percentage resistant of $S$. aureus isolated from otitis media against several antibiotics 
Tow isolates were selected due to multiple antibiotic resistance therapy, in order to evaluate bacteria susceptibility to antibiotic that revealed earlier by disk diffusion test when examined against antibiotics. The results of MIC were shows in Table 2, In this Table
S2 had high-level of resistance were $(16 \mu \mathrm{g} \backslash \mathrm{ml})$ for chloremphenicol, amoxicillin and ampicillin, while $(128 \mu \mathrm{g} \backslash \mathrm{ml})$ for cefotaxime, Where as S5 were $(32,64$ and $128 \mu \mathrm{g} \backslash \mathrm{ml})$ for amoxicillin, ampicillin, chloremphenicol and cefotaxime respectively.

Table 2. MIC value of some antibiotics for $S$. aureus $(\mathbf{S 2}, \mathrm{S5})$ isolates

\begin{tabular}{|lllll|}
\hline Isolate No. & C $\mu \mathrm{g} \backslash \mathrm{ml}$ & $\begin{array}{c}\text { AMX } \\
30 \mu \mathrm{g} \backslash \mathrm{ml}\end{array}$ & $\begin{array}{c}\text { CTX } \\
10 \mu \mathrm{g} \mid \mathrm{ml}\end{array}$ & $\begin{array}{c}\text { AMP } \\
25 \mu \mathrm{g} \mid \mathrm{ml}\end{array}$ \\
\hline S2 & & 16 & 128 & 16 \\
S5 & 64 & 32 & 128 & 32 \\
\hline
\end{tabular}

C: Chloramphenicol, AMX: Amoxicillin, CTX: Cefotaxime., AMP; Ampicillin

The results of the antibacterial activities of the slightly inhibitory effect on S5 while have no onion extracts against $S$. aureus organisms were shown in Table 3, after $24 \mathrm{hr}$ using Minimal inhibitory concentration was determined via macro broth dilution method. It was found that at $8 \mu \mathrm{g} \backslash \mathrm{ml}$ of onion extract a effect on S2. However at 16 and $32 \mu \mathrm{g} \backslash \mathrm{ml}$ showed good inhibitory were observed against S2 and S5. While at 64 and $128 \mu \mathrm{g} / \mathrm{ml}$ completely inhibit the growth of S2 and S5

Table 3. MIC value for Onion extract on $S$. aureus $(\mathrm{S2}, \mathrm{S5})$ after $24 \mathrm{hrs}$

\begin{tabular}{|c|c|c|c|c|c|c|}
\hline \multirow{2}{*}{$\begin{array}{l}\text { Type of } \\
\text { isolate }\end{array}$} & \multicolumn{6}{|c|}{ Concentration of onion $\mu \mathrm{g} \backslash \mathrm{ml}$} \\
\hline & $8 \mu \mathrm{g} \backslash \mathrm{ml}$ & $16 \mu g \backslash m l$ & $32 \mu \mathrm{g} \backslash \mathrm{ml}$ & $64 \mu \mathrm{glml}$ & $128 \mu \mathrm{g} \backslash \mathrm{ml}$ & \\
\hline S2 & +++ & & & + & - & - \\
\hline S5 & ++ & & & - & - & - \\
\hline
\end{tabular}

$+:$ Indicates growth of $S$. aureus and $-:$ no growth

Indicates growth of $S$. aureus and - : no that the concentrations (32, 64 and $128 \mu \mathrm{g} / \mathrm{ml})$ growth

Table 4 reveals the results of MIC of onion extract on $S$. aureus after $72 \mathrm{hrs}$. It was found were more effective in inhibition growth of (S2, S5) while $(8 \mu \mathrm{g} / \mathrm{ml})$ showeed heavy growth of $S$. aureus.

Table 4. MIC value for Onion extract on S. aureus $(\mathrm{S2}, \mathrm{S5})$ after $72 \mathrm{hrs}$

\begin{tabular}{|c|c|c|c|c|c|c|}
\hline \multirow{2}{*}{$\begin{array}{l}\text { Type .of } \\
\text { isolate }\end{array}$} & \multicolumn{6}{|c|}{ Concentration of onion $\mu \mathrm{g} \backslash \mathrm{ml}$} \\
\hline & $8 \mu \mathrm{g} \backslash \mathrm{ml}$ & $16 \mu g \backslash m l$ & $32 \mu \mathrm{g} \backslash \mathrm{ml}$ & $64 \mu \mathrm{g} \backslash \mathrm{ml}$ & $128 \mu \mathrm{g} \backslash \mathrm{ml}$ & \\
\hline S2 & + & & & - & - & - \\
\hline S5 & + & & & - & - & - \\
\hline
\end{tabular}

+: Indicates growth of P.aeruginosa and - : no growth The $\mathrm{pH}$ of each of the onion solution were (6.8, 7.0, 7.2, 7.4, 7.6 and 7.8). Result demonstrated that no $\mathrm{pH}$ effect on the onion activity has been observed. The onion extract have antibacterial activity due to the presence of flavonoids and polyphenols which has been reported to have broad spectrum of antibacterial activity (19).Also these activity belongs to they do not act directly on bacteria but create an adverse environment for them, thus causing threate their survival and they have also been found to decrease the resistant strains of microorganisms (3) .This property belongs to the onion constituent sulphur compounds, thromboxanes and by inhibiting the action of platelet-activating factor (PAF) exhibits its antimicrobial activity mainly by immediate and total inhibition of RNA synthesis, although DNA and protein syntheses are also partially inhibited (16). The greater sensitivity with largest zone of inhibition was observed with ciprofloxacin. This result was in agreement with another by Reese, R., R. Betts, and B. Gumustop. 2000 (32) who found that ciprofloxacin was effective in the treatment of the virulent gram positive bacteria including $S$. aureus. From this result of Table (1) one could conclude that ciprofloxacin remain the first choice when most isolates were sensitive to it. Because of resistance for ciprofloxacin included effective suction pump of the antibiotic from inside to outside to escape its effect and prevent the accumulation of antibiotic inside bacterial cell (29) .Ciprofloxacin inhibit bacterial DNA gyrease, so preventing the super coiling of 
DNA, a process that is necessary for compacting chromosomes into the bacterial cell (10) and this was concluded that plasmid mediated $\beta$-lactamase conferred high level resistance to penicillin and cephalosporin antibiotics and the level of resistance depend on the amount of $\beta$-lactamase produced so the mechanism (35) (36) that account for increase production of plasmid-determined $\beta$-lactamase include mutations or insertion elements that alter the promoter strength, microscopy plasmid and gene duplications (33) .The number of multiple antibiotic resistance strains has been increasing since resistance is mainly mediated by $\mathrm{R}$ - plasmids, which determined $\beta$ lactamase in Gram positive rod (25)'All the Rplasmids carried the markers of resistance to chloraemphenicol, tetracycline, ampicillin, gentamycin and streptomycin (5).Results of MIC showed that $S$. aureus infections are more difficult to treat because the organism's high intrinsic resistance antimicrobial agents; this resistance is partly due to its relatively low outer membrane permeability (6). However there are other mechanisms that included decreasing the passage into or increasing the efflux of drug from bacterial cell and modification of the target site (6). Our results its matches with (11) who founded that both lower and higher concentration of petroleum ether, ethyl acetate and chloroform extracts of onion which inhibited the Staphylococcus aureus growth. In contrast, the Butanol, ethanol and water extracted of onion at any concentration were ineffective to control the growth of Staphylococcus aureus.Our results its matches with Mohamed Eltaweel. 2013 (28) who founded that the onion extract has antibacterial activity against Staphylococcus aureus. It has shown that dilute solutions of onion can completely inhibit the growth of $S$. aureus at the concentration of more than 16 $\mu \mathrm{g} / \mathrm{ml}$. From our study it was concluded that $S$. aureus were highly prevalence among teenager age of otitis patients and high prevalence of antibiotic resistance was observed among $S$. aureus isolates especially to penicillin cefotaxin and tetracycline and it was found that onion extract has considerable inhibitory effects against the tested $S$. aureus isolates.

\section{REFERENCES}

1. Ahn, K. 2017. The worldwide trend of using botanical drugs and strategies for developing global drugs. BMB. 50 (3): 111-116.

2. Al-Gbouri. and A. G. Hamza. 2018. Evaluation of phyllanthus mplica xtract as antibacterial and antibiofilm against biofilm formation bacteria. Iraqi Journal of Agricultural Science.49(1).

3. Ani, V., M. Varadaj, and K.Naidu.2006. Antioxidant and antibacterial activities of polyphenolic compounds from bitter cumin (Cuminum rigrum L.), European Food Res Technol, 224 (1) P: 109 -115

4. Atlas, R., L. Parks, and A. Brown.1995. Laboratory Manual of Microbiology. $1^{\text {st }}$ ed Mosby, Inc. Missori

5.Bakht, J., K. Shehla, and M. Shafi.2013. Antimicrobial potentials of fresh Allium cepa against gram positive and gram negative bacteria and fungi. Pak. J. Bot. 45(1):1- 6

6. Bera, A., S. Herbert, A. Jakob, W. Vollmer, and F.Gotz. 2005. Why are pathogenic Staphylococci lysozyme resistant. The peptidoglycan $O$ - acetyletransferase oat Ais the major determinant for lysozyme resistance of Staphylococcus aureus. Mol.Microbial.55:778-787

7. Bisen, S. and E.Mila.2016. Nutritional and therapeutic potential of garlic and onion (Allium sp.). Current Nutrition \& Food Science.12(3):190-199

8. Blumenthal, M., and W. Busse.1998. Goldberg The Complete German Commission E Monographs, Austin, TX: American Botanical Council. : 176-177.

9. Brook, I., and S. Finegold 1979. Bacteriology of chronic otitis media. J.A.M.A. 241:487-488

10. Chambers, H. 2001. The changing epidemiology of Staphylococcus aureus Emerg. J. Infect. Dis.7 (2): 182-278

11. Collins, L., C. Kristain, M. Weidemier,K. Faigle, J. Van Kessel,E. Strij, B. Gőtz, B. Neumeiser, and A. Pesche. 2002. S.aureus strains lacking d-alanine modification of teichoic acid are highly susceptible to human neutrophil Killing and are human virulence attenuated to mice. J. Infect. Dis. (186):214219 
12. Cowan, M. 2001. plant products as antimicrobial agents. Clinical microbiology Reviews. 12(4):564 582

13. De, N., and E. Ifeoma. 2002. Antimicrobial effects of components of the bark extracts of neem. Azadirachta indica A. Juss.Technol. Dev. 8: 23-26

14. El-Meleig, M., M. Ahme, R. Arafa, N. Ebrahim and E. El Kholany. 2010. Cytotoxicity of four essential oils on some human and bacterial cells, J. Appl. Sci. in Environ Sanit. 5: 143-159.

15. Feinmesser, R., Y.Wiesel, and $M$. Argaman. 1982.Otitis externa - bacteriological survy. ORL. J. (44): 121-125

16. Foster, T., and D. McDevitt.1994. Molecular Basis of Adherence of Staphylococci to Biomaterials. P.31, In Bisno Al, Waldvogel FA (eds): Infections Associated with Indwelling Medical Devices, $2^{\text {nd }}$ ed. American Society for Microbiology, Washington, D.c

17. Gates, G. A. 1998. Acute otitis media and otitis media with effusion. In Cumming, C. W., Fredrikson, J. M., Harker, L. A., Krause, C. J. and Schuller, D. E. Otolaryngology Head and Neek Surgery.ed.(3).St. Louis,CV .Mosby.:2808- 2822

18. Hannan, T., M. Humayun, M. Hussain, S.Yasir, and S. Sikandar. 2010 .In vitro antibacterial activity of onion (Allium cepa) against clinical isolates of Vibrio cholera, $\mathrm{J}$ Ayub Med Coll Abbottabad. 22(2):160163.2010

19. Hendrich, A. 2006. Flavonoid-membrane interactions: possible consequences for biological effects of some polyphenolic compounds. Acta Pharmacologica Sinica. 27(1): $27-40$

20. Ibraheem, R. M., A.A. Mhawesh, K .W. Abood. 2018. Estimation of the flavonoid, antioxidant, antibacterial challenge concerning Viola odorata (Banafesha) methanolic extract. Iraqi Journal of Agricultural Sciences, 49(4):655-662

21. Jaber, M., and A. AlMossawi.2007.Susceptibility of some multiple resistant bacteria to garlic extract. Afr. J. Biotechnol. 6 (6): 771-776

22. Karam, I. F.A. 2016. The effect of some fresh water Aleaa extract in the inhibition of the growth of some microorganism that cause food spoilage. Iraqi Journal of Agricultural Science. 47(4).

23. Khalili, H., R. Soltani, S. Negahban, A. Abdollahi, and K.Gholami.2012. Reliability of disk diffusion test results for the antimicrobial susceptibility testing of nosocomial grampositive Microorganisms. Iran J Pharm Res. 11(2): 559-563

24. Konuku, S., M. M.Rajan, and S. Muruhan. 2012. Morphological and biochemical characteristics and antibiotic resistance pattern of Staphylococcus aureus isolated from grapes. International Journal Of Nutrition, Pharmacology,Neurological Diseases.2(1):7073

25. Lacey, R.1980. Evidence of two mechanisms of plasmids transfer in mix culture of Staphylococcus aureus. J . Gen. Microbial. (119):423-424

26. Lampe, J.1999. Health effects of vegetables and fruits: assessing mechanisms of action in human experimental studies. Am J Clin Nutr .70:475-90.

27. Lanzotti, V.2006. The analysis of onion and garlic. J. Chromatogr., A. 1112: 3-22.

28. Mohamed Eltaweel .2013. Assessment of antimicrobial activity of onion extract (Allium cepa) on Staphylococcus aureus ; in vitro study. International Conference on Chemical, Agricultural and Medical Sciences (CAMS2013) Dec.: 29-30

29. Muller, M., M. Brunner, M. Hollenstein, U. Joukhadar, C. Schmid, R. Minar and H. Eicher. 1999. Penetration of ciprofloxacine into intersitiial space of inflamed foot lesions in non- insulin- dependent diabetes mellitus patient. Antimicrobs. Agents Chemother. 43(8):2056-2058

30. National Committee for Clinical Laboratory Standard, Performance standard for antimicrobial disc susceptibility testing, Twelfth [International Supplement; Approved standard M100-S12, National Committee for Clinical Laboratory Standards, Wayne, Pa, 2002.

31. Onyeagba, R., O. Ugbogu, C. Okeke, and O. Iroakasi.2006. Studies on the antimicrobial effects of garlic (Allium sativum Linn), ginger (Zingiber officinale Roscoe) and lime (Citrus aurantifolia Linn). Afr. J. Biotechnol. 3(10): $552-554$ 
32. Reese, R., R. Betts, and B. chemistry of potential therapeutic agents, Gumustop.2000.Resistant bacteria to garlic and onion extract. Afr. J. Biotechnol. 6 (6): 771-776

33. Rohrer, S. and B. Berger. 2003 Fem ABX peptidyletransferases: a link between branched-chain cell wall peptide formation and $\beta$-lactam resistance in Gram-positive cocci. Antimicrob. Agents Chemother. (47):837-846

34. Rose, P., M. Whiteman, P. Moore, and Y. Zhu.2005. Bioactive S-alk (en) yl cysteine sulfoxide metabolites in the genus Alliums: the Natural Product Rep. 22: 351-368

35. Zedan, T., M. Al-Jailawi, and K. Jassim. 2013. Determination of K1 and K2 capsular serotypes for Klebsiella pneumoniae using magA and k2A genes as specific molecular diagnosis tools, Int. J. of Biolog. and Pharma. Res., 4(12): 1283-1288

36. Zeidan, I. 2007. Bacteriological and Genetic Study on Different Clinical Samples of Staphylococcus aureus Resistance to Vancomycin. M.Sc. Thesis in Biotechnology, College of Science/Baghdad University. pp:90-92. 